\title{
REFLECTIONS ON THE POLITICAL THOUGHT OF THE IRISH
}

\section{REVOLUTION*}

\author{
By Richard Bourke
}

READ 9 SEPTEMBER 2016

AT THE UNIVERSITY OF TEESSIDE

\begin{abstract}
Examining the political thought of the Irish Revolution poses two distinct problems. First we need to establish how we should date the Revolution for the purposes of intellectual history. There is no doubting that the 1916 Easter Rising was an event in British and Irish politics, but it was also an event in the world of ideas. Any serious consideration of this episode and its aftermath therefore needs to trace its origins to patterns of thought as well as shifts in affairs, and the two processes do not necessarily coincide. The second requirement for understanding the role of political thought in the Revolution is to reconstruct carefully the actual doctrines articulated and deployed. Irish historians have been reluctant to engage in this process of interpretation. Yet a more searching account of political ideas in the period has the potential to change our approach to the Revolution as a whole.
\end{abstract}

Any general discussion of the political thought of the Irish Revolution requires clarification at the outset of at least two things: first, we have to specify what the 'Irish Revolution' is supposed to cover; and, second, we need to delineate what we mean by 'political thought'.

Let me begin with the concept of revolution. By the time the events which are today described as the Irish Revolution took place, the modern idea of revolution had a long established pedigree going back to $1789 .{ }^{1}$ The French case introduced the notion of decisive rupture - of a deliberately radical disruption in the course of history that reconfigured society and politics altogether. Recently, at least one historian has argued that the revolutionary characteristics that are standardly ascribed to the French 'deluge' could equally be applied to $1688 .^{2}$ Thus, the Glorious Revolution did not amount to a process of pragmatic adaptation, Steve Pincus has argued, challenging standard wisdom from Burke to Macaulay; instead it involved the violent overthrow

\footnotetext{
*My thanks to Ultán Gillen and Roisín Higgins for organising the symposium at which this lecture was delivered, and to the Royal Historical Society for their support.

${ }^{1}$ The classic text on the distinctly revolutionary character of the French Revolution is of course Edmund Burke, Reflections on the Revolution in France Edmund Burke, ed. J. C. D. Clark (Stanford, CA, 2001), whose arguments have been variously deployed ever since - by advocates and detractors alike. For further discussion of the general theme, see Hannah Arendt, On Revolution (New York, 1963); François Furet, Penser la révolution française (Paris, 1978); Reinhart Koselleck, 'Historische Kriterien des neuzeitlichen Revolutionbegriffs' in idem, Vergangene Zukunft: zur Semantik geschichtlicher Zeiten (Frankfurt am Main, 1979); John Dunn, 'Revolution' in Terence Ball, James Farr and Russell L. Hanson (eds), Political Innovation and Conceptual Change (Cambridge, 1989). ${ }^{2}$ Steve Pincus, 1688: The First Modern Revolution (New Haven, CT, 2009).
} 
of a regime. ${ }^{3}$ Yet however one interprets the Glorious Revolution, it is clear that it did not inaugurate the modern tradition of revolution. In subverting a regime it did not challenge a complete 'order', relegating the annals of previous history to the status of an ancien régime.

Similarly, the American Revolution of 1776 never claimed to be a comprehensive annulment of past values. Beginning in 1765, much American protest against parliamentary taxation self-consciously sought to restore a pre-existing state of affairs. A decade later the mood had certainly shifted, and a new agenda had been set. But even then, as insurrection gathered momentum among outraged colonists, there was no absolute denial of all legitimating principles associated with conditions under the Empire. A generation of scholars managed to demonstrate that the original upheaval in the colonies drew on venerable political doctrines. ${ }^{4}$ Many of these were backward looking in character. In fact, according to one prominent historian, even the putative 'radicalism' of the Revolution was a betrayal of the republican ethos of the American founding. ${ }^{5}$ More recently it has been shown how the struggle over the constitution re-deployed constitutional principles developed over the previous hundred and thirty years. ${ }^{6}$ The unqualified denial of the validity of an epoch began in France in 1789.

In light of this observation, it is worth noting that at least one commentator has seen fit to argue that the principles guiding the Revolution in Ireland amounted to nothing new. Instead, old ideas were recycled again for use by a new class of rulers. ${ }^{7}$ There may be something to this, though surely it is overstated. It seems implausible to deny cultural experimentation, and even intellectual innovation, to the protagonists of the Irish Revolution, including those who fashioned themselves as mere conduits for earlier streams of thought. And besides, the simple fact of a transfer of power to wholly new personnel tells its own story. Who rules whom, Lenin saw, is a basic question in politics; and the answer certainly changed in Ireland in the early twentieth

\footnotetext{
${ }^{3}$ Ibid., esp. 3-48.

${ }^{4}$ See, classically, Bernard Bailyn, The Ideological Origins of the American Revolution (Cambridge, MA, 1967).

${ }^{5}$ Gordon Wood, The Radicalism of the American Revolution (New York, 1992).

${ }^{6}$ Eric Nelson, The Royalist Revolution: Monarchy and the American Founding (Cambridge, MA, 2014).

${ }^{7}$ D. G. Boyce, Nationalism in Ireland (London, 1982; $3^{\text {rd }}$ ed., 1995), 312.
} 
century. ${ }^{8}$ The spectacle of public control and political authority suddenly falling to a new cadre of politicians, along with the establishment of new forms of allegiance among the population at large, is clearly indicative of revolutionary change to the organising structure of a society.

So there seems to be little difficulty in depicting the relevant events in Ireland as revolutionary in nature, though what kind of revolution has yet to be determined. Any such effort at specification has to be a fundamentally comparative exercise, though such a perspective is barely to be found in the existing literature. Since the republican tradition in Ireland traces its lineage to the enlightenment, attempts at comparison should begin with the late eighteenth century. ${ }^{9}$ Yet it soon becomes clear that although Irish revolutionaries invoked eighteenth-century precedents, the earlier period provided nothing like an exemplary model that the Irish followed. For instance, the Irish Revolution was quite different from the American, even though there have been intelligent bids to equate the two episodes. ${ }^{10}$ To begin with, the Americans revolted reluctantly against parliamentary 'tyranny', building militant resistance that won incremental support, whereas the Irish were moved to sever a parliamentary union at the behest of a vanguardist conspiracy. That is not to say that there is nothing to compare - the most interesting overlap is the persistence of British loyalism in both cases, which was more diffuse, although still considerable, in the case of America. ${ }^{11}$ Yet it is to say that America cannot be viewed as a precedent.

Equally, the French Revolution was not adopted as a template in Ireland, even if it was invoked by some as an inspiration. The pivotal drama in the Irish case, the rising of 1916, cannot credibly be described as 'Ireland's 1789 '. ${ }^{12}$ To begin with, the French established some kind of a parliamentary monarchy in 1789 , not a republic, or a constitutional democracy. Events in France began with telling divisions within the military, and proceeded by political encroachment on state power. Matters then advanced by a transfer of control over the armed forces. Polarisation in due course led to purges, and annexations, but never to partition; and France throughout remained a

\footnotetext{
${ }^{8}$ On the Leninist criterion, see Raymond Geuss, Philosophy and Real Politics (Princeton, NJ, 2008), $23 \mathrm{ff}$.

${ }^{9}$ On the earlier period, see Ultán Gillen, 'Le directoire et le républicanisme Irlandais', in P. Serna, Républiques sœurs: Le directoire et la révolution atlantique (Rennes, 2009).

${ }^{10}$ Roy Foster, Vivid Faces: The Revolutionary Generation in Ireland, 1890-1923 (London, 2014), xvii.

${ }^{11}$ See Leonard W. Labaree, 'The Nature of American Loyalism', Proceedings of the American Antiquarian Society, 54 (April 1944), 15-58; Maya Jasanoff, Liberty's Exiles: American Loyalists in the Revolutionary World (New York, 2011).

${ }^{12}$ For 1916 as Ireland's 1789, see Foster, Vivid Faces, p. 14.
} 
major European power. Nonetheless, despite these salient differences, key aspects of the Irish Revolution do stand at least in the 'tradition' of 1789. Yet this very fact underlines its derivative character, thus fundamentally distinguishing it from the spirit of its French precursor. In Ireland there occurred a definitive break with what went before, but the idea of a breach as such was nothing new: the conception of revolution was not revolutionised. Moreover, the canon of values to which the Irish appealed actually existed in the world, and already had complicated histories to their names. Thus by 1923 on the island of Ireland there was a new polity and two new regimes, but not an unprecedented style of politics. Finally, even while revolutionaries in Ireland might be placed in a tradition that began in 1789, France's revolutionary experience, including 1848 and 1871, was characterised by the variety of its forms. The idea of a revolutionary tradition has been imaginatively seductive, but in fact each new instalment of revolt in France diverged importantly from 1789, making the notion of an unbroken heritage an ideological fabrication. ${ }^{13}$

The Irish Revolution was therefore in some sense part of a continuity, obliging us to reflect on its various aspects comparatively, while also recognising that it was very much its own thing. Some of the problems involved in anatomising its features are revealed by the difficulty in defining its historical limits. The view that it was brought to an end in 1923 has rarely been disputed, although it has been claimed that it really ended in 1921, succeeded by a movement of counter-revolution lasting until 1936. ${ }^{14}$ Of course, 'counter-revolution' has both morally charged and blandly descriptive usages. ${ }^{15}$ In descriptive terms, a militant assault on the settled path of a revolution constitutes a counter-revolution. It is often a matter of fine judgement what a 'settled' course of development is, and so in practice the difference between a revolution and a counter-blow can be difficult to determine, leaving us wondering, for

\footnotetext{
${ }^{13}$ For the seductions of the revolutionary tradition in France, see John Plamenatz, The Revolutionary Movement in France, 1815-1871 (London, 1952); Albert Soboul, 'Tradition et création dans le mouvement révolutionnaire française au XIX ${ }^{\mathrm{e}}$ siècle', Le mouvement social, 79 (April-June 1972), pp. 15-31; Patrick H. Hutton, The Cult of the Revolutionary Tradition: The Blanquists in French Politics, 1864-1893 (Berkeley and Los Angeles, CA, 1981); Christine Piette, 'Réflexions historiques sur les traditions révolutionnaires à Paris au XIX ${ }^{\mathrm{e}}$ siècle', Historical Reflections/Réflexions historiques, 12 (1985), 403-18.

${ }^{14}$ John Regan, The Irish Counter-Revolution, 1921-1936: Treatyite Politics and Settlement in Independent Ireland (Dublin, 1999).

${ }^{15}$ Its normatively inflected meaning is largely indebted to the Marxist philosophy of history: see, classically, Friedrich Engels, Revolution und Konterrevolution in Deutschland (1851-1852) in Karl Marx und Friedrich Engels, Werke (Berlin, 1956-1990), 43 vols, VIII, 5-108. For a sociological analysis see Charles Tilley, 'An Analysis of Counter-Revolution', History and Theory, 3:1 (1963), 3058.
} 
example, whether Jacobinism was the fulfilment of 1789 or a violent conspiracy against it. ${ }^{16}$ The term is usually burdened with ideological baggage, based on moral intimations of a 'true' revolutionary spirit. Thus, depending on one's taste, antitreatyites in Ireland can be seen as a betrayal of revolutionary pragmatism, or as a continuation of the Revolution's original purpose. But of course on either reading the main struggle in Ireland ended in 1923, as revolution and counter-revolution congealed into a settlement.

Unlike the terminus of the Revolution in Ireland, its beginnings have been much debated. One of the earliest endeavours to discover its origins appeared at the end of the civil war. W. Alison Phillips's 1923 study, The Revolution in Ireland, traced the transformation of Irish politics to $1906 .{ }^{17}$ This periodisation may be odd, but it is not completely without any rationale. In February of that year Henry Campbell-Bannerman led the Liberals to a landslide victory, ending just over a decade of Tory rule. In theory, this spelled the end of committed unionism in power, though in truth the issue of Home Rule was contained until the election of 1910, when John Redmond's Irish Parliamentary Party secured the balance at Westminster. There then followed the Parliament Act the following year, preparing the way for the introduction of Home Rule. Since this is the issue that proved explosively divisive in Irish politics, one might better (even on Phillips's assumptions) date the Revolution from the Liberal alliance with the Irish party, beginning in 1910.

Yet all this is to trace the origins of the crisis to the rhythms of parliamentary politics. For this reason, Alison Phillips's lead has rarely been followed. More plausible as a starting point is 1912 . This lends primary significance to the reaction to Asquith's Home Rule bill, which mobilised a determined unionist opposition, led to the assertion of a Protestant general will in Ulster, and the founding of a popular militia in Ireland for the first time in over one hundred and thirty years. It was these events that convinced Eoin MacNeill, and indeed Patrick Pearse, that 'the north began'. ${ }^{18}$ Popular sentiment in the northeast was inflamed, the bargaining power of militancy was publicly demonstrated, and constitutional propriety was fatally undermined. Yet still, to fixate on this date is to privilege unionist dissent as the chief

\footnotetext{
${ }^{16}$ The former case has been variously articulated, from Burke to Furet; the latter case has most recently been put by Jonathan Israel in Revolutionary Ideas: An Intellectual History of the French Revolution from The Rights of Man to Robespierre (Princeton and Oxford, 2014).

${ }^{17}$ W. Alison Phillips, The Revolution in Ireland, 1906-1923 (Dublin, 1923).

${ }^{18}$ Eoin MacNeill, 'The North Began', An Claidheamh Soluis, 1 November 1913.
} 
driver towards confrontation. For this reason, historians have sometimes preferred to settle on 1858, when James Stephens founded the Irish Republican Brotherhood; or 1879 , when organised agitation over land began in earnest; or 1891, when the fall of Parnell shattered Catholic confidence in parliamentarism; or 1916, when the slide toward bloody conflict became irreversible. ${ }^{19}$

Two other moments in time deserve serious consideration. As the examples of Michael Davitt, Roger Casement and Sean MacBride make plain, the Boer War encouraged Irish opposition to imperialism among a generation who lost faith in the righteous pretentions of British rule. Even more decisive, of course, was the Great War itself, without which the Easter Rising, and its results, are inconceivable. Roy Foster correctly identified the formative character of these events as having contributed to the 'radicalization' of politics in Ireland. ${ }^{20}$ Yet in general terms the impact of international developments has been under-emphasised, although Irish awareness of the wider world in the period has been recently demonstrated. ${ }^{21}$ Above all, the transformative significance of the First World War needs to be accentuated - a vital context, as Theda Skocpol saw, for the Russian Revolution, just as it was for developments in Ireland. ${ }^{22}$

The War immediately altered popular attitudes to violence, from some perspectives promising a rebirth of noble valour after a Victorian age of enervating peace. 'There are few men in whom the blast of the bugles of war do [sic] not arouse the fighting instinct', James Connolly commented in February $1916 .{ }^{23}$ As soon as the cause of the War began to look hollow, revivified patriotism was free to pin its hopes on other apparently more elevated causes. For Connolly, of course, the War amounted to 'fratricidal slaughter'. ${ }^{24}$ It was a 'war for civilisation' that destroyed the conditions of civilisation. As early as August 1914, the vista of depravity appeared so vast to him that even a vain attempt at socialist revolution by 'force of arms' would have the

\footnotetext{
${ }^{19}$ See, respectively, Tom Garvin, Nationalist Revolutionaries in Ireland, 1858-1928 (Oxford, 1987); D. G. Boyce, The Revolution in Ireland, 1879-1923 (Basingstoke, 1988); Roy Foster, Modern Ireland, 1600-1972 (London, 1988, 1989), 431 ff.; Peter Hart, The I.R.A. at War, 1916-1923 (Oxford, 2003), esp. chapt. 1.

${ }^{20}$ Foster, Modern Ireland, 456.

${ }^{21}$ Maurice Walsh, Bitter Freedom: Ireland in a Revolutionary World, 1918-1923 (London, 2015).

${ }^{22}$ Theda Skocpol, States and Social Revolutions: A Comparative Analysis of France, Russia and China (Cambridge, 1979).

${ }^{23}$ James Connolly, 'What is a Free Nation?', Worker's Republic (12 February 1916) in The Revolutionary and Anti-Imperialist Writings of James Connolly, 1893-1916, ed. Conor McCarthy (Edinburgh, 2016), 247.

${ }^{24}$ James Connolly, 'A Continental Revolution', Forward (15 August 1914) in ibid., 216.
} 
advantage at least of paralysing the economic vitals of the War. ${ }^{25}$ In due course he lowered his sights: the War might not be stopped in its tracks, but the tradition of resistance could be kept alive by an insurrectionary 'leap in the dark' ${ }^{26}$ In short, given that a culture of militarism had spread since 1914, opposition was increasingly disposed to make its stand in battle. At the same time, the sense that resistance would be self-defence increased throughout the period: first the suppression of the Volunteers was fairly widely expected, then the prospect of conscription began to seem an immediate threat long before it was finally unfurled in April 1918. In the United Kingdom, the War not only eroded the pacific protocols of civil life, it also fostered potentially inimical patriotisms. The year 1914, we have to conclude, was a game changer.

For all the possible richness of discussion that debate over the origins of the Irish Revolution is capable of stirring, Easter 1916 must retain its peculiar significance as the moment when Irish nationalism made a military stand, and opinion began to turn against British authority. However, equally clearly, the political ideas that proved influential during the Revolutionary tumult pre-date the actual uprising itself. It makes sense to privilege political events in plotting the outlines of the Irish Revolution since affairs were so conspicuously propelled by dramatic deeds. Yet we still need to accept that, fundamentally, the Revolution was an intellectual-political episode, and that its intellectual origins did not begin in 1916. These, according to Pearse, should be traced to 1893 . There had been two revolutions in Ireland, he observed in 1914: the second was the founding of the Volunteers - first north, then south - but before that it was the establishment of the Gaelic League that had been transformative. ${ }^{27}$ The intellectual history of the Irish Revolution began in the 1890s, he was arguing. Thomas Davis was the 'lineal ancestor' of the League, which rejuvenated the consciousness of nationality. ${ }^{28}$ The successful raising of consciousness was a prophecy according to Pearse; it was, indeed, 'more than' a

\footnotetext{
${ }^{25}$ Ibid., 217.

${ }^{26}$ James Connolly, 'Last Testament' in ibid., 244, 255.

${ }^{27}$ Pádraic H. Pearse, 'How Does She Stand II: Robert Emmet and the Ireland of Today' (1914) in Collected Works of Pádraic H. Pearse: Political Writings and Speeches (Dublin, Cork and Belfast, 1924), 73.

${ }^{28}$ Pearse, 'The Spiritual Nation’ (13 February 1916), ibid., 304.
} 
prophecy. It looked forward to the assertion of nationality in arms. ${ }^{29}$ There occurred, in other words, a long gestation. ${ }^{30}$

As this last remark implies, W. B. Yeats in broad outline agreed with Pearse. Cultural efflorescence, a new 'stir of thought', seemed to him to have likewise begun in the 1890s. He traced the moment specifically to 1891 when the fate of Parnell disillusioned the public with parliamentary agitation. It was at that moment, Yeats thought, that the war of independence was effectively conceived. Later commentators have rightly challenged Yeats's rigid fatalism, yet they have also tended to misconstrue his point. ${ }^{31}$ He never argued that the succession of literary, cultural and intellectual movements after 1891 should be viewed as an 'alternative' to politics, which, as Pearse made plain, they were not. Instead, Yeats viewed the 'stir of thought' as an alternative to parliamentarism: not politics altogether, but parliamentary politics - the cut and thrust of quotidian deliberation and compromise that were coming to be viewed as corrosive of principle.

This observation fits with a more widely felt sentiment in the period - namely, that parliamentary methods were somehow jaded and counterproductive, and that therefore other means of cultivating new values were needed. ${ }^{32}$ There was no benefit that parliament could confer on the Irish people, Connolly believed, that could not be 'extorted by the fear of a revolutionary party'. ${ }^{33}$ Scepticism about Westminster only grew over the following decade. 'People speak as if the outcry against Parliamentarianism were a novel and unique thing', Tom Kettle observed in $1908 .{ }^{34}$ Eight years later in the House of Commons William O'Brien spoke of an accumulated 'loathing of Parliamentaryism' that underlay the impulse to rebellion. ${ }^{35}$ Direct action seemed more effective and authentic. In fact the view that political struggle was

\footnotetext{
${ }^{29}$ Pearse, ‘The Coming Revolution' (November 1913), ibid., 91.

${ }^{30}$ On this see W. B. Yeats, 'The Irish Dramatic Movement' (Nobel Lecture, 15 December 1923) in idem, Dramatis Personae: Autobiographies (London, 1936), 177: 'The modern literature of Ireland... and indeed all that stir of thought that prepared for the Anglo-Irish war, began when Parnell fell from power in 1891. A disillusioned and embittered Ireland turned from Parliamentary politics; an event was conceived; and the race began, as I think, to be troubled by that event's long gestation'. The motif of a 'long gestation' has been influential in the historiography of the period. See, for example, Patrick Maume, The Long Gestation: Irish Nationalist Life, 1891-1918 (Dublin, 1999).

${ }^{31}$ Foster, Modern Ireland, 431-2.

${ }^{32}$ This sentiment had a wider European resonance, culminating in Carl Schmitt, Die geistesgeschichtliche Lage des heutigen Parlamentarismus (Munich, 1923).

${ }^{33}$ James Connolly, 'Patriotism and Labour' (August 1897), Shan Van Vocht in Writings of Connolly, 29.

${ }^{34}$ Louis François Alphonse Paul-Dubois, Contemporary Ireland (Dublin, 1908), ix.

${ }^{35}$ House of Commons Debates (Hansard), 24 July 1916, vol. 84., col. 1456.
} 
epiphenomenal went back at least to Marx, Kettle had remarked. Yet for him there were nonetheless limits to this anti-parliamentary rhetoric: cultural development could only fully prosper under conditions of achieved political autonomy, and that required a parliamentary strategy.

So debate about the relationship between culture and politics was pervasive. For some, like Kettle and O'Brien, the parliamentary campaign was a precondition of national self-expression. For Yeats and Pearse the relationship worked the other way round: consciousness was to be refashioned by intellectual means, creating new opportunities for shaping public life in general. Either way, cultural rebirth was refashioning public consciousness. As Connolly put it as early as 1897, 'Irish Language movements,' 'Literary Societies' and 'Commemoration Committees' were 'helping to save from extinction the precious racial and national history, language and characteristics of our people' ${ }^{36}$ The danger was that recourse to tradition would trap politics in retrospect. Nonetheless, a forward looking programme required cultural sustenance too.

The revival of national sensibility was also charted by Erskine Childers. In his 1911 monograph, The Framework of Home Rule, he set out the 'various movements' - 'agricultural, industrial, economic, literary, political' - which amounted to proximate demonstrations of home rule in operation. ${ }^{37}$ Explicitly following Lecky, Childers argued that public spirit was the only viable antidote to sectarianism in Ireland ${ }^{38}$ In practice this meant fostering national institutions. The principle of nationality was an expression of an irrepressible urge for political freedom, which in Ireland would best be expressed through devolved government. Interestingly, for Childers the 'ideas' of Sinn Fein, if neither its methods nor ultimate objectives, were indices of the same spiritual striving. It was these very ideas, he went on, that 'animate the Industrial Development Associations, the Co-operative movement, the thirst for technical instruction, the Gaelic League, the literary revival, and the work of the only truly Irish organ of government, the Department of Agricultural and Technical Instruction' ${ }^{39}$ Thus, as far as Childers was concerned, since the 1890 s there

\footnotetext{
${ }^{36}$ James Connolly, 'Socialism and Nationalism' (January 1897), Shan Van Vocht in Writings of Connolly, 23.

${ }^{37}$ Erskine Childers, The Framework of Home Rule (1911), 155.

${ }^{38}$ Ibid., 183.

${ }^{39}$ Ibid., 168.
} 
had emerged new movements, new associations, new programmes and new thought, including 'political thought' in a broadly understood sense.

Here we need to pause to consider what we mean by political thought, the second objective of this lecture that I signalled at the start. This task is somewhat onerous since the terrain is so thinly populated. With a very few distinguished exceptions, there has been no intellectual history of this period in Ireland, let alone a self-conscious effort to examine its political thought. ${ }^{40}$ Sometimes it is assumed that an intellectual history of political 'troubles' involves dignifying base opportunism with a veneer of idealism; or that the absence of 'great' political thinkers around 1916 implies that no thinking about politics occurred - or at least none that could merit sustained attention. These adverse assumptions are then compounded by the occasional argument that ideology played no decisive role in Ireland at the time. Diarmaid Ferriter has recently argued that there is no evidence of "sophisticated ideological debate' in Ireland between 1913 and $1923 .{ }^{41}$ In fact he seems to argue that reflective discussion came later, rather inverting the actual sequence of events. Given the serious intellectual interventions made by home rulers, socialists, feminists, unionists and separatists in the period, it is remarkable to imply that intelligent argument had somehow ceased.

However it is true that reconstructing the debates is a demanding task. The difficulty is twofold: first it is necessary to trawl a dismaying array of sources, and second these have to be placed in their appropriate milieux. The most prominent and successful histories of political thought since the 1960s have for the most part dealt with a canon of classic texts, most of these steeped in extended European and Anglophone traditions, and cast in explicitly philosophical idioms. Revolutionary thought in Ireland in the early twentieth century is altogether less architectonic in style, and media other than the treatise predominate. Journalism in its various forms enjoyed a peculiar importance. The primary object of analysis is perforce less canonical, and rarely addressed exclusively to a political and scholarly elite. Clearly journalism and the popular tract did not begin in the twentieth century. Their roots lie in the seventeenth and eighteenth. Nonetheless in Ireland in the period under examination, these are the principal materials with which the historian of ideology has

\footnotetext{
${ }^{40}$ One exception is Nicholas Mansergh, Ireland in the Age of Reform and Revolution (1940). The book was reissued as The Irish Question, 1840-1921: A Commentary on Anglo-Irish Relations and on Social and Political Forces in Ireland in the Age of Reform and Revolution (1965).

${ }^{41}$ Diarmaid Ferriter, A Nation and Not a Rabble: The Irish Revolution, 1913-1923 (2015), 9.
} 
to deal. Understanding them historically requires particular forms of attention. The kind of contextualism that has predominated in the study of political thought is unsurprisingly inadequate to the task. The framing contexts employed by 'Cambridge'-trained historians of ideas have been explicitly intellectual in type: thus, ideas have largely supplied the context for ideas, with (for example) Machiavelli being explained in terms of his use of classical sources, and Locke in terms of Filmer and Pufendorf. ${ }^{42}$

In many ways this is a product of an understandable division of labour. Everyone accepts that in principle all contexts are potentially relevant to the interpretation of canonical authors. Keith Thomas demonstrated the importance of social context for Thomas Hobbes, and Quentin Skinner originally argued that political context was required to make proper sense of Leviathan. ${ }^{43}$ Yet in practice the Cambridge School has largely focussed on intellectual context, even among nineteenth century specialists (for instance Gareth Stedman Jones, Stefan Collini, John Burrow and Donald Winch).$^{44}$ We can all agree that this involves a constricted conception of context, although we can also see why a historian might narrowly focus on the intellectual milieu of Locke: the research involved in mastering the sources is laborious. The same limitations hardly apply to studying the political ideas of the Irish Revolution. Intellectual context of course remains important. Indeed it is remarkable how little work has been done on Pearse's or Connolly's sources. But cultural context has to assume some kind of prominence since so many of the relevant figures were expressly involved in cultural projects. And political context, of course, is indispensable.

While a broad conception of context is therefore essential, so too is careful analysis of the various positions proposed. By 'analysis' I mean close attention to how the argument works - its key propositions, its underlying assumptions, and its organising principles. It is this that has been strikingly lacking in Irish histories of the

\footnotetext{
${ }^{42}$ The classic texts here are John Dunn, The Political Thought of John Locke: An Historical Account of the Argument of the 'Two Treatises of Government' (Cambridge, 1969); J. G. A. Pocock, The Machiavellian Moment: Florentine Political Thought and the Atlantic Republican Tradition (Princeton, NJ, 1975); Quentin Skinner, The Foundations of Modern Political Thought (Cambridge, 1978), 2 vols.

${ }^{43}$ Keith Thomas, 'The Social Origins of Hobbes Political Thought' in Hobbes Studies, ed. K. C. Brown (Oxford, 1965); Quentin Skinner, 'Conquest and Consent: Hobbes and the Engagement Controversy' in G. E. Aylmer ed., The Interregnum: The Quest for Settlement, 1646-1660 (1972).

${ }^{44}$ Gareth Stedman Jones, An End to Poverty? A Historical Debate (London, 2004); John Burrow, Stefan Collini and Donald Winch, That Noble Science of Politics: A Study in Nineteenth-Century Intellectual History (Cambridge, 1983).
} 
period. For instance, given his prominent role in the Rising itself, it is notable how little work has been done on Connolly as an intellectual figure. There has been no real scrutiny of the political ideas of Tom Kettle, and little close examination of the arguments of Childers. Women writers have fared altogether better, not least thanks to work done by Senia Pašeta. ${ }^{45}$ By comparison, there has been little sensitive handling of the political works of Pearse. The biographical treatments have been substantially based on psychological speculation, with little careful analysis of his writings. ${ }^{46}$ In the same vein, there is much to be done with the elder Plunkett, Casement and Carson, as well as Robert Lynd, Arthur Griffith, Alice Stopford Green, and Eoin MacNeill. All too often, some of these figures have been treated as fairly mindless bearers of prejudice rather than as vehicles for concerted thought. This is partly because of an anti-intellectual strain in Irish history writing, but also because relevant doctrines tend to be blamed rather than discussed: blamed, that is, for their consequences, or their 'intrinsic' tendencies.

This outcome is partly a product of the habit of reducing thought to 'attitudes', or inchoate 'emotional' responses. Of course, intellectuals do have attitudes, but their ideas are not simply an extension of them. Hegel experienced moods, and possessed a sensibility, but the Philosophy of Right is more than a mere reflection of them. Yet the same is true of George Russell, D. P. Moran and Louie Bennet. ${ }^{47}$ A recurrent problem among Irish historians is well illustrated by Tom Garvin in his innovative study of nationalist revolutionaries in Ireland. Garvin explicitly drew on the political sociologist Barrington Moore and the Czech historian Miroslav Hroch to argue that an insurrectionary spirit was encouraged by social resentment among a rising generation of Catholic nationalists. ${ }^{48}$ So the meaning of revolutionary nationalism is reduced to a shared posture, determined by the relative social position of its emissaries. This style of argument is originally indebted to Karl Mannheim who proposed to characterise

\footnotetext{
${ }^{45}$ Senia Pašeta, Irish Nationalist Women, 1900-1918 (Cambridge, 2013).

${ }^{46}$ This is conspicuously the case in the standard studies: their authors were so keen to dismantle a thendominant hagiography that they could not condescend to take their subject's thought at all seriously. See, for instance, Ruth Dudley Edwards, Patrick Pearse: The Triumph of Failure (1979).

${ }^{47}$ A. E. [George Russell], 'Nationality and Imperialism' in Ideals in Ireland, ed. Lady Gregory (1901); D. P Moran, The Philosophy of Irish Ireland (Dublin, 1905); Louie Bennett, Ireland and a People's Peace: Paper read by Miss Louie Bennett at a Joint Meeting of the Irishwomen's International League and the Irish Section of the Union of Democratic Control, Feb. 27, 1918 (Dublin, 1918).

${ }^{48}$ Garvin, Nationalist Revolutionaries, 6-8, using arguments indebted to Barrington Moore, The Social Origins of Dictatorship and Democracy (Harmondsworth, 1969) and Miroslav Hroch, Die Vorkämpfer der nationalen Bewegungen bei den kleinen Völkern Europas (Prague, 1968).
} 
social philosophies in terms of the backgrounds of their proponents. ${ }^{49}$ Locating a figure socially naturally makes good sense if we want to understand where they are coming from. But assuming we know their ideas because we can guess their attitudes is just another way of saying that we don't need to read their work.

In this way, publicists and thinkers become vectors of abstractions instead of actors with intricate intentions: they are made into exemplars of 'revolutionary romanticism', gratuitous 'supremacists' or deluded 'solipsists'. ${ }^{50}$ At worst they become the expression of a 'syndrome' ${ }^{51}$ The net result is that ideology is reconstructed under the influence of social and political theories developed after the fact rather than the opinions of the protagonists actually involved. A recent attempt to return us to the perspectives of the original actors offers a welcome map of Revolutionary 'mentalities'. ${ }^{52}$ But here again the emphasis is on 'attitudes' rather than ideas, or at least ideas are more often presented than examined. In many ways this follows quite naturally from the Annales style of history, from which the preoccupation with mentalités derives. ${ }^{53}$ Peter Burke has traced the Annales approach to eighteenth- and nineteenth-century precursors: distantly to Voltaire's Essai sur les moeurs, but more immediately to Jacob Burkhardt, Jules Michelet and Fustel de Coulanges. ${ }^{54}$ Yet this may amount to lumping all histories of manners and opinions into a single, indiscriminate pile, whereas in fact the characteristic concern of Marc Bloch and Lucien Febvre with 'mémoire collective' or shared 'representations' was meant to identify deep-set, enduring structures of belief - hardly a notable interest among nineteenth-century historians. More importantly, for our purposes, longuedurée forms of mental activity are very distinct from revolutionary thought. As Jacques Le Goff has written, 'the historian of mentalities will tend to move towards the ethnologist: both seek to discover the stablest, most immobile level of a society's existence' ${ }^{55}$ By comparison, social and political upheaval is accompanied by new

\footnotetext{
${ }^{49}$ Karl Manheim, Essays on the Sociology of Knowledge (1952).

${ }^{50}$ F. S. L. Lyons, Ireland since the Famine: 1850 to the Present (1971, 1973, 1990), 330; J. J. Lee, Modern Ireland: 1912-1985 (Cambridge, 1989, 1992), 2-4; Richard English, Irish Freedom: The History of Nationalism in Ireland (2006), 274.

${ }^{51}$ Oliver MacDonagh, States of Mind: A Study of Anglo-Irish Conflict 1780-1980 (1983, 1992), 89.

${ }^{52}$ Foster, Vivid Faces, xvii-xviii.

${ }^{53} \mathrm{My}$ thanks to Colin Jones for discussing this tradition with me.

${ }^{54}$ Peter Burke, The French Historical Revolution: The Annales School, 1929-2014 (Cambridge, 1990, 2014), chapt. 1 .

${ }^{55}$ Jacques Le Goff, 'Mentalities: A History of Ambiguities' in Constructing the Past: Essays in Historical Methodology, ed. Jacques Le Goff and Pierre Nora (Cambridge, 1985), 167.
} 
attitudes and ideas. The relevant ideas might not be globally innovative, but they are likely to be transformative in context - as indeed, in the case of Ireland, they were.

The reluctance among Irish historians to examine the political theory as well as the background consciousness of the Revolutionary generation has meant that ideology in the early twentieth century has been constructed after the fact in accordance with pre-established schemes of interpretation. ${ }^{56}$ Cumulatively, this has brought about a situation in which the period has too often been approached in terms of positions that have been manufactured on the basis of ideal doctrines assembled by academics generations later. The most common abstract theory employed by historians is that of 'nationalism', which is assumed to capture the essence of the Revolution in Ireland. However, rather strangely, ideas of nationalism advanced at the time are rarely examined. Instead, ingredients from Hans Kohn, John Plamenatz, Benedict Anderson, Eric Hobsbawm and Ernest Gellner are collected, and projected (somewhat haphazardly) onto opinion in the earlier era. ${ }^{57}$ Curiously, however, the doctrine is projected inconsistently, ascribed almost exclusively to the self-styled 'nationalist' party, as if national sentiment were only a property of Irish Catholics, when clearly some kind of national allegiance mobilised Ulster Protestants and determined the actions of the British state.

The most popular claim is that nationalism was peculiarly destabilising because it combined political ambition with religious sentiment. ${ }^{58}$ However, more recent studies have underlined the range of religious conviction among revolutionary activists, from obsessive piety to anti-clericalism. ${ }^{59}$ It is clear that Catholicism will be

\footnotetext{
${ }^{56}$ On the difference between 'political theory' and 'political consciousness', see Eric Nelson, 'What Kind of Book is the Ideological Origins' (forthcoming).

${ }^{57}$ Hans Kohn, The Idea of Nationalism: A Study in its Origins and Background (New York, 1944); John Plamenatz, 'Two Types of Nationalism' in Nationalism: The Nature of an Evolution of an Idea, ed. Eugene Kamenka, (Canberra, 1975); Benedict Anderson, Imagined Communities: Reflections on the Origin and Spread of Nationalism (London, 1991); Eric Hobsbawm, Nations and Nationalism since 1780: Programme, Myth, Reality (Cambridge, 1990); Ernest Gellner, Nations and Nationalism (Ithaca, NY, 1983).

${ }^{58}$ English, Irish Freedom, 274. The claim derives immediately from Conor Cruise O'Brien. On O'Brien in this context, see Richard Bourke, 'Languages of Conflict and the Northern Ireland Troubles', Journal of Modern History, 83:3 (2011), 544-78. O’Brien's underlying assumption has a longer history, mediated by Raymond Aron, and going back to Alexis de Tocqueville and Edmund Burke. The claim is in any case based on a misreading of both Burke and Tocqueville. See Raymond Aron, 'L'avenir des religions séculières' (1944), Commentaire, 8:28-29 (1985), pp. 369-83; Alexis de Tocqueville, The Old Regime and the Revolution (1856), trans. Alan S. Kahan (Chicago, IL, 19982001), 2 vols, I, 99-101; Edmund Burke, Second Letter on a Regicide Peace (1796) in The Writings and Speeches of Edmund Burke, ed. Paul Langford (Oxford, 1970-2015), 9 vols., IX, 278.

${ }^{59}$ Foster, Vivid Faces, p. 36.
} 
found among nationalists who are Catholic, but it does not follow that their nationalism will be uniquely 'mystical', or that fanaticism is its inevitable product.

For L. T. Hobhouse writing about Ireland in 1912, nationalism was continuous with liberal principle insofar as it contributed to the 'democratic cause' ${ }^{60}$ Democracy thus understood was devoted to terrestrial improvement, and so was not in any obvious sense religious in nature. The principle of democracy comprised two elements, Hobhouse thought. First it required the existence of popular consent, and second it depended on effective representation. Both were absent, he believed, in the case of Ireland in 1912. 'A free government', he contended, '...must be founded on the voluntary adhesion of the mass of the people' ${ }^{61}$ Yet there was no evidence of broad-based support for the Union in Ireland. At the same time, it was structurally impossible for Irish interests to find a hearing at Westminster. By this he did not mean that Irish MPs had no leverage, which they clearly did, but that the government of Ireland did not reflect Irish preferences. It was this set-up that led to widespread complaints that, despite the Union, Ireland was a colonial dependent on metropolitan power, rather than a free political agent. 'It may have equality of franchise', Hobhouse wrote, 'but its representatives are in a permanent minority' ${ }^{62}$

Hobhouse's intervention demonstrates two things. First it shows that debate about nationalism in the period turned on constitutional questions that are not reducible to controversy over 'identity', in contrast to more recent academic analysis. ${ }^{63}$ Second it provides an example of competing conceptions of nationalism. There was no single doctrine of nationalism shared by activists at the time, but rather a rich diversity in understandings. To comprehend this diversity, and thus to appreciate the issues that galvanised contemporary actors, we must return to the original sources in the appropriate spirit: that means, in the spirit of historical criticism - not taking professions of faith at face value, but nonetheless aiming to reconstruct them dispassionately. Paul Bew began this task in relation to Redmondism

\footnotetext{
${ }^{60}$ L. T. Hobhouse, 'Irish Nationalism and Liberal Principle' in J. H. Morgan ed., The New Irish Constitution: an Exposition and Some Arguments (1912), 361.

${ }^{61}$ Ibid., 364.

${ }^{62}$ Ibid., 365.

${ }^{63}$ Typical of the idiom is Anthony D. Smith, National Identity (Harmondsworth, 1991).
} 
and unionism, and Matthew Kelly has probed the intricacies of Fenianism. ${ }^{64}$ Yet still the full complexity of republicanism remains under-explored.

As commonly represented in the historiography, Irish republicanism is interpreted as a doctrine of exclusion. This charge is hardly meaningless, but it has been inadequately understood. A good example of the intricacies can be found in Pearse, with whom I'll conclude.

Pearse presented himself ostentatiously as standing in the tradition of Wolfe Tone. Tone, he believed, preached a philosophy of inclusion, not exclusion. As Pearse put it, Ireland was not populated by two nations, or three, but by a single, inclusive culture, comprising Catholic, Protestant and Dissenter. ${ }^{65}$ Naturally this meant inclusion on republican terms, which for Pearse's opponents could mean nothing but exclusion. Nonetheless, Pearse's principles of inclusion are worthy of exploration in their own right. His programme was addressed to people of 'every rank and class', and of all sections of opinion. ${ }^{66}$ Yet not all members of each section were expected to lend their support. Pearse saw himself as a spokesman for a democratic agenda that did not require active popular endorsement. Mass sentiment might be corrupted, leaving a minority to represent pre-existing popular rights. Most usually, he commented in 1915, it is 'the few' who fight for what is right, the many for what is wrong. Yet it is the few, he believed, who, ultimately, 'win'.

What licences the few, then, to act on the majority's behalf? The answer here, though sometimes difficult to grasp, is that it is democratic principle that authorises a minority to act as unelected delegates of the many. As Pearse argued a matter of months before the Easter Rising, the goal of republicanism was to put the people, 'the actual people', 'in effectual ownership and possession of the soil of Ireland' ${ }^{68}$ This did not necessarily entail a wholesale redistribution of wealth, but rather the right of the sovereign nation to dispose of its resources. The same point was articulated in the Easter Proclamation: 'We declare the right of the people of Ireland to the ownership of Ireland and to the unfettered control of Irish destinies, to be sovereign and

\footnotetext{
${ }^{64}$ Paul Bew, Ideology and the Irish Question: Ulster Unionism and Irish Nationalism, 1912-1916 (Oxford, 1994); Matthew Kelly, The Fenian Ideal and Irish Nationalism, 1882-1916 (Woodbridge, 2006).

${ }^{65}$ Pearse, 'Oration on Wolfe Tone' (1913), Political Writings, 59.

${ }^{66}$ Pearse, 'Oration on Robert Emmet' (1914), Political Writings, 73.

${ }^{67}$ Pearse, 'The Separatist Idea' (1 February 1916), Political Writings, 215.

${ }^{68}$ Pearse, 'The Sovereign People' (31 March 1916), Political Writings, 350.
} 
indefeasible'. ${ }^{69}$ The final determination of property was a national right, even if in practice possessions were to be held in private hands. It is not this determination that resides with the few, but the right to create conditions in which it can be made. So while the exercise of democracy derives from an electorate, the right of selfgovernment might be asserted by a derisively small number.

What then were the origins of this right? In Pearse's view self-determination is a natural right, prescribed at once by natural law and the law of nations, although access to that right can only be sustained by tradition. ${ }^{70}$ That means, on the one hand, that Pearse's argument is contractual. On the other hand the right of contract is transmitted by tradition. So, primordially a people might contract with itself to govern. For Pearse this means that a people is not entitled to betray its liberty, 'any more than a contract of perpetual slavery is binding on an individual' ${ }^{71}$ For this reason he could write that 'the national demand of Ireland is fixed and determinate'. ${ }^{72}$ It could not be modified by transitory, popular whim. Yet it could expire from generalised neglect. As soon as the historical memory of nationality disappeared, there would be no basis on which to assert the primordial right of self-government. Consequently, Pearse ascribed nationality to tradition: while the original entitlement to form a democracy was pre-historic, a natural right could only retain its force in history if it was periodically realised in action.

In Ireland the right to self-government pre-dated the Norman Conquest: 'It will be conceded to me that the Irish who opposed the landing of the English in 1169 were Separatists', Pearse wrote. ${ }^{73}$ From that point on the knowledge of nationality was transmitted historically. Consciousness of the right to self-determination was preserved by exemplary acts of personal sacrifice across the generations. It was in this sense that national tradition had to be treated with reverence: 'Patriotism is like a religious faith', Pearse asserted. Note that it was like, but was not in fact, a religious faith. ${ }^{74}$ The faith was kept alive through the memory of the dead 'striving' to accomplish some unfinished task. Pearse's political vision was therefore fundamentally secular. His doctrines were, if anything, a threat to Christian

\footnotetext{
${ }^{69}$ Poblacht na hÉireann, para. 3.

${ }^{70}$ For natural law, see Pearse, 'Ghosts' (Christmas 1915), Political Writings, 230.

${ }^{71}$ Ibid., 231.

${ }^{72}$ Ibid., 230.

${ }^{73}$ Ibid., 232.

${ }^{74}$ Pearse, 'Oration on Robert Emmet' (1914), Political Writings, 66.
} 
orthodoxy. The people, not Christ, is the messiah, he once proclaimed. It is true that the messiah was to be foreshadowed by a Christ-like sacrifice ${ }^{75}$ But once again the very analogy amounts to a Christian heresy.

Sacrifice, we need to understand, was not intended as self-immolation. It was a vivid means of generating consent. Accordingly, the sacrificial stand of Easter Monday was not 'symbolic', but pragmatic, a protest in arms that might, at best, awaken immediate support or, at worst, inspire as an example of public virtue. As with the Romans, Pearse wagered, a show of virtue might generate mass appeal. Minimally it might garner support for separatist insurrection. It was for this reason that Pearse could view bloodshed as 'a cleansing and a sanctifying thing' ${ }^{76}$ This was not a simple cult of wanton violence. After all, Pearse had been vociferous in his condemnation of Redmondism as 'a peace-holocaust' that spilled the blood of fifty thousand Irishmen. ${ }^{77}$ War, he believed, was terrible, but slavery was worse. Like Gandhi, Pearse followed a train of English authors from Carlyle to Ruskin in condemning the culture of utility as having inured the people to slavery. ${ }^{78}$ The first duty of the Irish democrat was therefore to preach heroism against self-interest as a prelude to the rebirth of national will. ${ }^{79}$ Sacrifice for one's country was a renunciation of self-advancement. The hope was that it would successfully transform popular consciousness; it was not an ideology of morbid failure.

The Irish Revolution was a republican revolution: assorted doctrines of republicanism lay at its heart. Any doctrine will appear exclusive to those who reject its principles. Unionism and republicanism were both built on exclusions with a view to advancing inclusion on their own terms. Republican exclusivism is usually opposed by liberal 'pluralism' in both the historical and political literature. Pluralism implies acceptance of the voices of dissent. From the vantage of now-dominant historiographical perspectives, republican orthodoxy occupies a dissenting position, and so a pluralist history is obliged to extend to it the requisite understanding. Understanding, naturally, does not mean approbation. Yet, equally, glib repudiation is a refusal to comprehend.

\footnotetext{
${ }^{75}$ Ibid., 69, 71.

${ }^{76}$ Pearse, 'The Coming Revolution' (November 1913), Political Writings, 99.

${ }^{77}$ Pearse, 'Ghosts' (Christmas 1915), Political Writings, 231-2.

${ }^{78}$ See Mahatma Gandhi, 'Hind Swaraj' and Other Writings, ed. Anthony J. Parel (Cambridge, 1997, 2009), 118 on key texts that guided the author's critique of English civilisation.

${ }^{79}$ Pearse, 'The Murder Machine' (1912), Political Writings, 25.
} 